\title{
FACTORS INFLUENCING THE EFFECTIVENESS OF TREASURY AND BUDGET MANAGEMENT INFORMATION SYSTEM (TABMIS) IN STATE TREASURIES IN HO CHI MINH CITY
}

\author{
NGUYEN THI THU HIEN ${ }^{1}$,CO THI THANH HUONG ${ }^{1}$, PHAM THI HONG NHUNG ${ }^{2}$, \\ PHAM TRUONG QUAN ${ }^{1}$ \\ ${ }^{I}$ Faculty Accounting and Auditing, Industrial University of Ho Chi Minh city, \\ ${ }^{2}$ School of Accounting and Auditing, University of Economics Ho Chi Minh city; \\ nguyenthithuhien@iuh.edu.vn, \\ cothithanhhuong@iuh.edu.vn,hoahong231210@gmail.com,phamtruongquan@iuh.edu.vn
}

\begin{abstract}
Applying information technology to state budget management is one of the solutions to improve transparency in public financial management, limit disadvantages in using budgets and ensure financial security in the process of national development and integration. In particular, implementing the treasury and budget management information system (TABMIS) is an important orientation in the treasury development strategy by 2020 of the Ministry of Finance of Vietnam. This study aims to analyze the critical factors affecting the effectiveness of TABMIS in state treasuries in Ho Chi Minh City. Using quantitative research method, the findings reveal that key factors included top management commitment and support; vendor support; implementation team; ERP user involvement; Data quality; infrastructure quality; TABMIS software quality; The management policies of TABMIS system, monitoring and control environment have a positive impact on the effectiveness of the TABMIS system, in which the monitoring and control environment factor has the strongest impact.
\end{abstract}

Keywords. Management Information system, TABMIS, the effectiveness, state treasury, Budget management.

\section{INTRODUCTION}

In the era of globalization along with the development of information technology, the deployment and application of Enterprise Resource Management (ERP) system is essential because this system helps organizations manage work effectively, quickly, provide timely and reliable information. Previous studies showed that ERP project success brings many advantages for organizations including increasing financial performance through efficient data processing, improving competitive position, and breaking down barriers interfering between departments, making it easy to exchange important data. Therefore, many countries have applied ERP business management software solutions in budget management to improve transparency and effectively control budget operations.

There are several papers studied the application of public sector ERP systems and the factors affecting system success (Ziemba and Oblak, 2013; Kalema BM et al., 2014). Omar MB \& Rami MAW (2016) analyzed the benefits of ERP application in Bahrain Kingdom public sector and key success factors (KSFs) affect the system, including (1) top management commitment and support; (2) ERP system matching organization; (3) business process re-engineering; (4) vendor support; (5) training users.

Because of benefits that ERP system brings, the World Bank (WB) and the International Monetary Fund (IMF) have published the "Treasury Reference Model - TRM", which outlines the fundamental operations of budget management model. This model is suitable for applying ERP software solutions in public sector. Therefore, the World Bank has funded many countries, especially developing countries, to implement this reference model based on ERP software solutions such as Kazakhstan, Mongolia, 
Slovakia, Kenya, Uganda, Indonesia... and Vietnam with WB-funded Treasury and Budget Management Information System (TABMIS) project, which has been implemented by the Ministry of Finance.

The TABMIS system has the function of supporting governmental accounting, which is important part of the system of financial and economic management tools, operating and controlling state budget activities. Therefore, in order to force the modernization reform process of the public finance sector as well as to support the project of the consolidated financial statements for the general governmental accounting, the effectiveness of the TABMIS system needs to be improved. Therefore, it is necessary to identify the factors affecting the effectiveness of the TABMIS system but there is very little research about TABMIS, and they mainly focus on qualitative research. Therefore, this study focused on identifying and analyzing the factors affecting the effectiveness of the TABMIS system with the scope of research being the State Treasury in HCM City. Research results will help the State Treasury evaluate the effectiveness of TABMIS system to better manage the state budget revenue and expenditure, provide reliable financial reports. The objectives of the study include two main topics: (1) Identify the factors affecting the effectiveness of TABMIS system at the State Treasury in Ho Chi Minh City; (2) Test the influence of factors on the effectiveness of the TAMIS system at the State Treasury in Ho Chi Minh City.

The remainder of the paper proceeds as follows. In the next section, we present an overview of past literature and our hypotheses; in section 'Institutional background', we provide institutional background; in Section 'Sample and variable construction' we present our sample and provide some descriptive statistics; in Section 'Research design', we describe our research design; in Section 'Results', we present our results; and in Section 'Additional findings and robustness checks', we discuss some additional findings and robustness checks. Section 'Conclusion' presents conclusions. C Â The structure of the study include the following elements: (1) Introduction; (2) Theoretical basis; (3) Research methods; (4) research model thuy êt her gi v à Daniel looks at the facilities; (5) Results of research u ; (6) Conclusion and recommendations

\section{LITERATURE REVIEW AND HYPOTHESES DEVELOPMENT}

\subsection{Successful information system model}

Delone \& McLean (1992) proposed a model, consists of six elements: system quality, information quality, service quality, intention to use/use, user satisfaction and net benefits, to measure a successful information system. The six serving variables are not a successful independent measure, but the interdependent variables are used to measure a successful information system. In 2003 and 2008, DeLone $\&$ McLean continues to update and expand the model on two levels of individuals and organizations. Many researchers used this model to find key success factors in each elements in both private and public sector.

\subsection{TABMIS system in governmental accounting at the State Treasury}

The Treasury and Budget Management Information System (TABMIS) is the largest component of the Ministry of Finance's Public Financial Management Reform Project. According to Oracle, TABMIS is defined as a centralized accounting system on computer networks, capable of connecting and exchanging information with other systems; At the same time, it is possible to provide full and timely reports in many criteria (report according to the standard design and customized requirements of the Ministry of Finance) to serve the management and administration requirements of the agency finance, State Treasury and authorities at all levels. TABMIS system is designed, built based on 4 bases: (1) Reference treasury model (TRM); (2) Accounting on an accrual basis; (4) Centralized payment account; (5) Classify account codes and unified budget indexes.

From 2012 until now, the TABMIS system has operated and operated in financial institutions and the State Treasury in 63 provinces and cities and in 40 central ministries. In the article of Ngo Hai 
Truong (2012) on the General Accounting, the author presents the results achieved when implementing TABMIS and solutions to improve TABMIS system. Pham Thi Thanh Huong (2013), when mentioning about risk control and prevention on TABMIS program, has identified the importance of the TABMIS account system in the State Treasury accounting. With the role of supporting data provision for synthesis and reporting, the TABMIS system has a great impact on the business process of budget management, raising budget accountability.

\subsection{Key success factors (KSFs) on Enterprise Resource Planning (ERP) system implementation in public sector}

Achieving the desired benefits, especially in public sector, the successful ERP implementation has been a challenge. To find solutions for this challenge, several KSFs for ERP implementation in public sector were identified in previous studies (e.g., Magaireh, A., Sulaiman, H., \& Ali, N., 2019; Omar \& Rami,2015; Ziemba, E., \& Oblak, I., 2013).

Ziemba, E., \& Oblak, I., (2013) examine critical success factors for ERP systems implementation in public administration in Poland. Their findings include four groups of factors, namely:

- factors related to public procurement procedure. This group has several factors such as: clear and precisely defined tender specification (information and government processes requirements, technological requirements, organizational requirements), realistic and chronologically arranged schedule, clear goals and objectives of the ERP system implementation.

- factors related to government processes management. These factors in this group are: frozen information requirements, identified government processes, government process reengineering.

- factors related to project team competences. The authors list project team competence on ERP systems, project team competence on public administration, use of consultants, cooperation with research centers, expertise in IT.

- factors related to project management such as: top management support, clear assignment of roles and responsibilities, change management, risk management, involvement ERP system end-users, interdepartmental communication, use of proven project management methodology, effective monitoring and control.

The results obtained from this research are helpful developing studies on ERP systems supporting processes in public administration as well as government agencies interested in implementing ERP systems.

Omar \& Rami (2015) examine key factors influencing the success of ERP system implementation in the public sector in the Kingdom of Bahrain. Their study focused on the following factors which are important for public sector: top management commitment and support, project management, ERP system matching the organization, user training and education, business process re-engineering, communication, change management, cultural factors, vendor support, implementation team, ERP user involvement. The finding shows the KSFs in the public sector in the Kingdom of Bahrain are top management commitment and support, ERP system matching organization, business process re-engineering, vendor support, and training users.

\subsection{Hypotheses Development}

In this study, we have examined the effects of nine key KSFs to measure ERP's successful implementation in public sector in State Treasury in Vietnam. These KSFs are (1) top management commitment and support, (2) consultant support, (3) project team competence, (4) user training and education, (5) data accuracy, (6) supporting tools and good infrastructure, (7) business process reengineering, (8) TAMIS management policies and (9) effective monitoring and control. The selected 


\section{FACTORS INFLUENCING THE EFFECTIVENESS OF TREASURY AND BUDGET MANAGEMENT INFORMATION SYSTEM (TABMIS) IN STATE TREASURIES IN HO CHI MINH CITY}

KSFs are among those that are widely cited as having a notable impact on the implementation success of the ERP systems but not for a particular system like TABMIS.

Based on the research results of Dantes \& Hasibuan (2011), Ziemba and Oblak (2013), Kalema BM et al (2014), Omar MB et al. (2016) combined with the study of characteristics of the State Treasury, the authors propose the following research hypotheses:

H1: The top management commitment and support positively affects the effectiveness of TABMIS system at the State Treasury in Ho Chi Minh City.

H2: Consultant support positively impact the effectiveness of TABMIS system at STs in Ho Chi Minh City.

H3: Project team competence positively impacts the effectiveness of TABMIS system at STs in Ho Chi Minh City.

H4: User training and education positively impact the effectiveness of TABMIS system at STs in Ho Chi Minh City.

H5: Data accuracy positively impacts the effectiveness of TABMIS system at STs in HCMC.

H6: Supporting tools and good infrastructure positively impact the effectiveness of TABMIS system at STs in Ho Chi Minh City.

H7: Business process reengineering positively impacts the effectiveness of TABMIS system at STs in Ho Chi Minh City.

H8: TAMIS management policies positively impacts the effectiveness of TABMIS system at STs in Ho Chi Minh City.

H9: Effective monitoring and control positively impact the effectiveness of TABMIS system at STs in Ho Chi Minh City.

The research model is showed in figure 2.1

(C) 2019 Industrial University of Ho Chi Minh City 


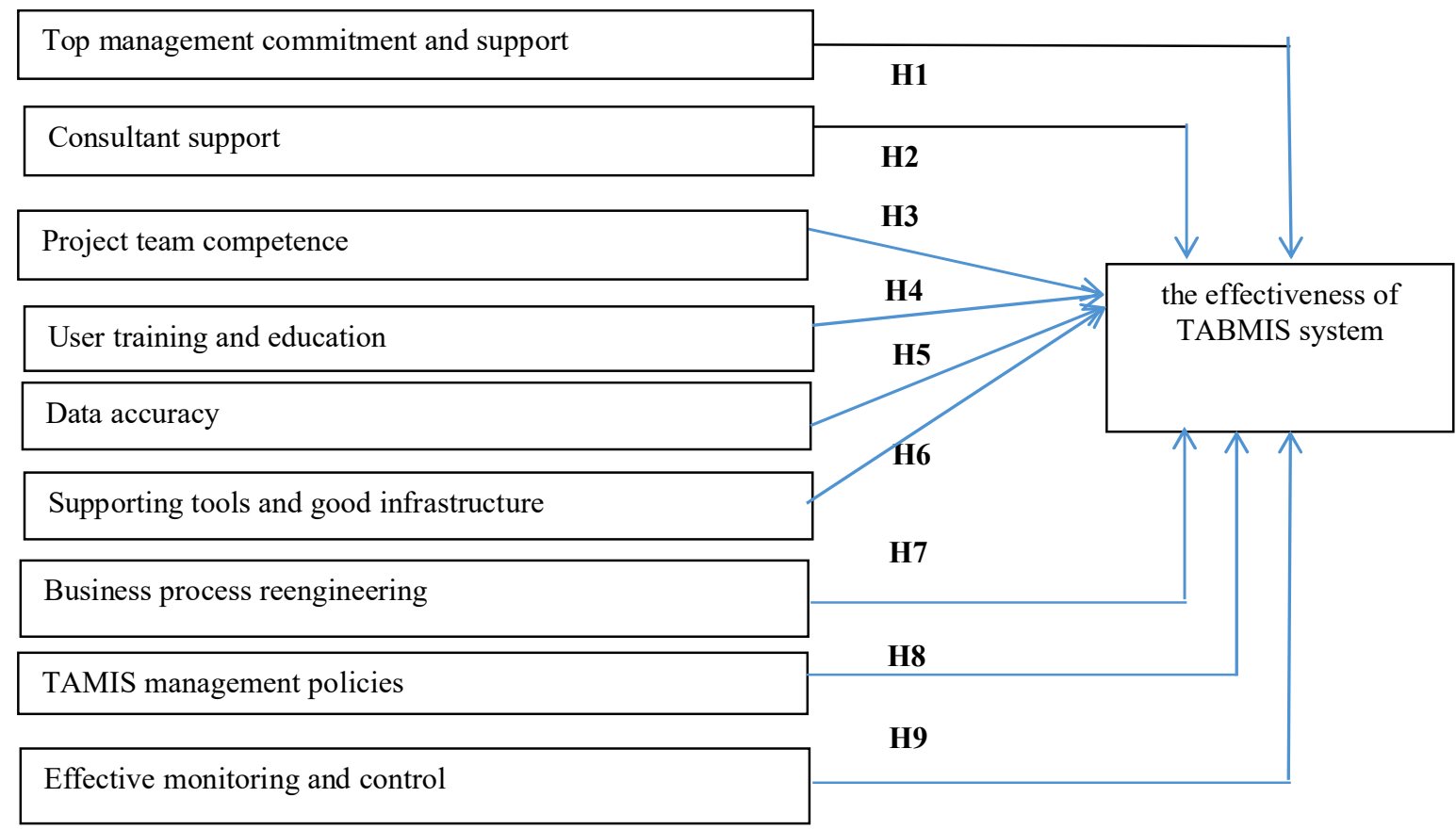

Figure 2.1. Research Model

\section{RESEARCH METHOD}

This study aims to identify and verify the impact of factors on the effectiveness of the TABMIS system and is implemented at the State Treasury in HCM City. Therefore, the paper combines qualitative and quantitative methods, in which quantitative research plays a key role.

Qualitative research methods: including integrated methods; Methods of analysis; Investigating, surveying, collecting opinions and collecting expert opinions; Descriptive statistics.

Quantitative research method: conducted with the number of survey samples $N=430$ and using Likert scale of 5 points: (1) Strongly disagree, (2) Do not agree, (3) No opinions, (4) Agree, (5) Strongly agree.

The scale is preliminarily tested by descriptive statistical tools, Cronbach's Alpha reliability factor, discovery factor analysis (EFA).Linear regression analysis is used to test models and evaluate hypotheses. The author divides the quantitative research process into 2 main steps: (1) Preliminary research to build the scale and preliminary assessment of the scale; (2) Test the adjusted research model.

\section{Methods of data collection}

- Interview with experts, the Board of Directors of the State Treasury, the staff of the IT department, the SAV at the State Treasury on TABMIS system and the factors affecting the TABMIS system at the State Treasury in HCM City.

- Designing a wide survey questionnaire for all public servants in departments working at the State Treasury in districts of HCMC, directly using the TABMIS system.

- Use the prepared questionnaire as Likert scale with 5 scales: 
$5=$ Strongly agree, $4=$ Agree, $3=$ Neutral, $2=$ Disagree, $1=$ Absolutely not I mean.

Preparation steps for data analysis: (1) After receiving the answer sheet, conduct information cleaning; (2) Encrypt the necessary information in the answer sheet; (3) Data entry and analysis with SPSS software version 20.

\section{RESULTS}

\subsection{Sample description}

We sent 450 surveys to the participants, the number of surveys collected were 430 . After manipulating data, the valid samples were 418 which is described in table 4.1.

Table 4.1. Descriptive Statistics for survey samples

\begin{tabular}{|c|c|c|c|}
\hline \multicolumn{2}{|c|}{ Sample allocation } & \multicolumn{2}{|c|}{ Surveys collected } \\
\hline & & Amount & Ratio (\%) \\
\hline \multirow[t]{2}{*}{ Sex } & Male & 139 & 33.3 \\
\hline & Female & 279 & 66.7 \\
\hline \multirow[t]{4}{*}{ Age } & Under 30 (1) & 85 & 20.4 \\
\hline & $30-39(2)$ & 164 & 39.2 \\
\hline & $40-49(3)$ & 151 & 36.1 \\
\hline & Over 49 (4) & 18 & 4.3 \\
\hline \multirow[t]{6}{*}{ Department } & Board of Directors & 26 & 6.2 \\
\hline & Accounting department & 299 & 71.5 \\
\hline & Administrative department & 48 & 11.5 \\
\hline & Inspection department & 11 & 2.6 \\
\hline & IT Department & ten & 2.4 \\
\hline & KSC Department & 24 & 12 \\
\hline
\end{tabular}

\subsection{Reliability Statistics with Cronbach Alpha}

Table 4.2. Results of running Cronbach Alpha

\begin{tabular}{|c|cc|c|c|c|}
\hline No. & \multicolumn{2}{|c|}{ Observed variable } & Variable Code & $\begin{array}{c}\text { Corrected Item - } \\
\text { Total Correlation }\end{array}$ & $\begin{array}{c}\text { Cronbach's } \\
\text { Alpha if variable } \\
\text { delete }\end{array}$ \\
\hline 1 & $\begin{array}{l}\text { Top management } \quad \text { commitment } \\
\text { support }\end{array}$ & and & $\begin{array}{l}\text { COMSUP1 } \\
\text { COMSUP2 }\end{array}$ & .802 & \\
& & & COMSUP3 & .805 & .802 \\
.808 & .928 \\
COMSUP4 & COMSUP5 & .841 & \\
\hline
\end{tabular}


FACTORS INFLUENCING THE EFFECTIVENESS OF TREASURY AND BUDGET MANAGEMENT

INFORMATION SYSTEM (TABMIS) IN STATE TREASURIES IN HO CHI MINH CITY

\begin{tabular}{|c|c|c|c|c|}
\hline 2 & Consultant support & $\begin{array}{l}\text { CONSULT1 } 1 \\
\text { CONSULT2 } \\
\text { CONSULT3 } \\
\text { CONSULT } 4 \\
\text { CONSULT5 }\end{array}$ & $\begin{array}{l}591 \\
.707 \\
.691 \\
.615 \\
.721\end{array}$ & .852 \\
\hline 3 & Project team competence & $\begin{array}{l}\text { PROTEAM1 } \\
\text { PROTEAM2 } \\
\text { PROTEAM3 } \\
\text { PROTEAM4 }\end{array}$ & $\begin{array}{l}.635 \\
.620 \\
.645 \\
.064\end{array}$ & .674 \\
\hline 4 & User training and education & $\begin{array}{l}\text { USER1 } \\
\text { USER2 } \\
\text { USER3 } \\
\text { USER4 } \\
\text { USER5 }\end{array}$ & $\begin{array}{l}.808 \\
.685 \\
.681 \\
.735 \\
.803\end{array}$ & .894 \\
\hline 5 & Data accuracy & $\begin{array}{l}\text { DATA1 } \\
\text { DATA2 } \\
\text { DATA3 } \\
\text { DATA4 } \\
\text { DATA5 } \\
\text { DATA6 }\end{array}$ & $\begin{array}{l}680 \\
.701 \\
.738 \\
.749 \\
.747 \\
.793\end{array}$ & .903 \\
\hline 6 & Supporting tools and good infrastructure & $\begin{array}{l}\text { INFRA1 } \\
\text { INFRA2 } \\
\text { INFRA3 }\end{array}$ & $\begin{array}{l}.565 \\
.644 \\
.639\end{array}$ & .777 \\
\hline 7 & Business process reengineering & $\begin{array}{l}\text { BPR1 } \\
\text { BPR2 } \\
\text { BPR3 } \\
\text { BPR4 } \\
\text { BPR5 } \\
\text { BPR6 }\end{array}$ & $\begin{array}{l}.640 \\
.650 \\
.669 \\
.664 \\
.797 \\
.785\end{array}$ & .886 \\
\hline 8 & TAMIS management policies & $\begin{array}{l}\text { MANAGE1 } \\
\text { MANAGE2 } \\
\text { MANAGE3 } \\
\text { MANAGE4 } \\
\text { MANAGE5 }\end{array}$ & $\begin{array}{l}.402 \\
.516 \\
.008 \\
.443 \\
.628\end{array}$ & .592 \\
\hline 9 & Effective monitoring and control & $\begin{array}{l}\text { CONTROL1 } \\
\text { CONTROL2 } \\
\text { CONTROL3 } \\
\text { CONTROL4 }\end{array}$ & $\begin{array}{l}.723 \\
.699 \\
.658 \\
.727\end{array}$ & .857 \\
\hline 10 & The effectiveness of TABMIS system & $\begin{array}{l}\text { EFFECT1 } \\
\text { EFFECT2 } \\
\text { EFFECT3 } \\
\text { EFFECT4 } \\
\text { EFFECT5 } \\
\text { EFFECT6 } \\
\text { EFFECT7 }\end{array}$ & $\begin{array}{l}.790 \\
.666 \\
.584 \\
.710 \\
.756 \\
.697 \\
.740\end{array}$ & .900 \\
\hline
\end{tabular}


Figure 4.2 shows that PROTEAM4 and MANAGE3 has a corrected item - total correlation of $<0.3$ so that it would be removed from the factor group, the remaining observed variables have a corrected item - total correlation $>0.3$, so they achieved reliability.

\subsection{Exploratory factor analysis}

Table 4.3. Table variance extracted independent factors

\begin{tabular}{|c|c|c|c|c|c|c|c|c|c|}
\hline \multirow{2}{*}{ Factor } & \multicolumn{3}{|c|}{ Initial Eigenvalues } & \multicolumn{3}{c|}{$\begin{array}{c}\text { Extraction Sums of Squared } \\
\text { Loadings }\end{array}$} & \multicolumn{3}{c|}{ Rotated Component } \\
\cline { 2 - 10 } & Total & $\begin{array}{c}\text { of } \\
\text { Variance }\end{array}$ & $\begin{array}{c}\text { Cumulative } \\
\text { \% }\end{array}$ & Total & $\begin{array}{l}\text { \% of } \\
\text { Varia } \\
\text { nce }\end{array}$ & $\begin{array}{c}\text { Cumulative } \\
\%\end{array}$ & Total & $\begin{array}{c}\text { \% } \\
\text { Variance } \\
\text { of }\end{array}$ & $\begin{array}{c}\text { Cumulative } \\
\%\end{array}$ \\
\hline 1 & 10,784 & 26.302 & 26.302 & 10,784 & 26.302 & 26.302 & 5.941 & 14,490 & 14,490 \\
3 & 4,479 & 10,925 & 37,227 & 4,479 & 10,925 & 37,227 & 5,311 & 12,953 & 27.444 \\
4 & 3,744 & 9,131 & 46,357 & 3,744 & 9,131 & 46,357 & 4,056 & 9,892 & 37,336 \\
5 & 2,492 & 8.273 & 54,630 & 3,392 & 8.273 & 54,630 & 4.017 & 9,797 & 47,133 \\
7 & 1.973 & 4,813 & 65,358 & 1.973 & 4,813 & 65,358 & 2,600 & 6.343 & 62,546 \\
8 & 1,420 & 3,464 & 68,822 & 1,420 & 3,464 & 68,822 & 2,573 & 6,276 & 68,822 \\
\hline
\end{tabular}

After using exploratory factor analysis (EFA), the scale is accepted and is divided into 7 independent factors and 1 dependent variable. In which, two independent variables "Consultant support" and "Project team competence" are grouped into 1 group; 2 independent variables "Data accuracy" and "Supporting tools and good infrastructure" into 1 group; In addition, the remaining independent variables in the model remain the same. We have the adjusted research model as figure 4.3 


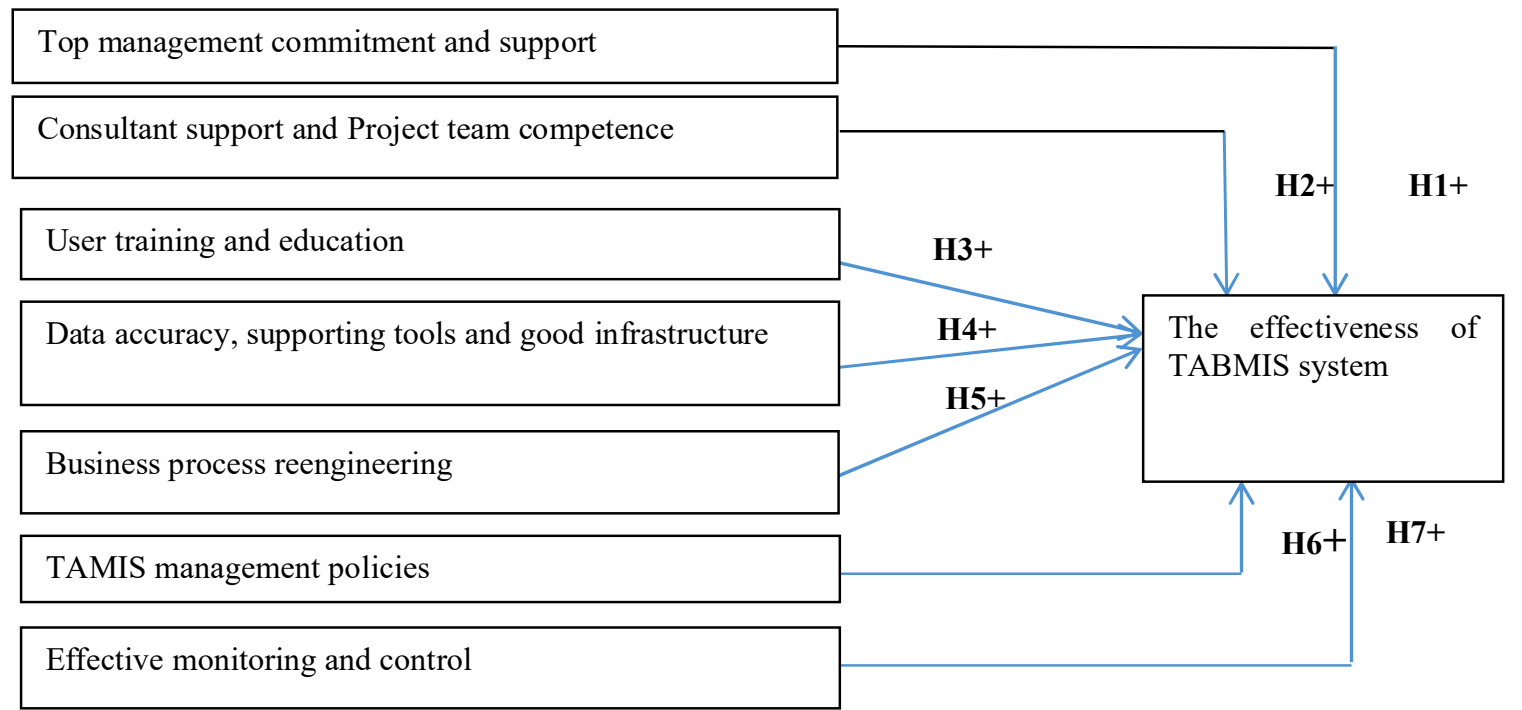

Figure 4.3: Adjusted research model

\subsection{Model and research hypotheses test}

Pearson correlation coefficient testing has a value of $<0.05$, so the independent variables in the model have a linear correlation with the dependent variable. Regarding the relevance of the model, the correlation coefficient value is $0.729>0.5$, so this is an appropriate model to use to evaluate the relationship between the dependent variable and the independent variables.

According to Table 4.4, all variables are statistically significant $\operatorname{Sig}=0.000<0.05$. VIF $<2$, so the multicollinearity doesn't appear. Linear regression equation:

EFFECT $=-6.41+0.126$ COMSUP + 0.148 CONSULTPROTEAM + 0.317 USER +

+ 0.110 DATAINFRA + 0.134 BPR + 0.134 MANAGE + 0.283 CONTROL

Table 4.4. Coefficients

\begin{tabular}{|c|c|c|c|c|c|c|c|}
\hline \multirow[b]{2}{*}{ Model } & \multicolumn{2}{|c|}{$\begin{array}{c}\text { The coefficient is not } \\
\text { standardized }\end{array}$} & \multirow{2}{*}{$\begin{array}{c}\begin{array}{c}\text { Standardized } \\
\text { coefficient }\end{array} \\
\text { Beta }\end{array}$} & \multirow[b]{2}{*}{$\mathbf{t}$} & \multirow[b]{2}{*}{ Sig. } & \multicolumn{2}{|c|}{ Multicollinearity } \\
\hline & B & $\begin{array}{c}\text { Standard } \\
\text { errors }\end{array}$ & & & & $\begin{array}{c}\text { Acceptance } \\
\text { of the } \\
\text { variable }\end{array}$ & VIF \\
\hline Constant & -641 & .164 & & $-3,918$ & .000 & & \\
\hline LEADER & .126 & .025 & .154 & 4,957 & .000 & .687 & 1,456 \\
\hline CONSULTPROTEAM & .148 & .022 & .188 & 6,631 & .000 & .824 & 1,213 \\
\hline USER & .317 & .032 & .284 & 9,880 & .000 & .803 & 1,246 \\
\hline DATAINFRA & .110 & .036 & .093 & 3,078 & .002 & .727 & 1,376 \\
\hline BPR & .134 & .032 & .117 & 4,146 & .000 & .829 & 1206 \\
\hline MANAGE & .134 & .031 & .123 & 4,380 & .000 & .833 & 1,201 \\
\hline CONTROL & .283 & .026 & .371 & 10,901 & .000 & .572 & 1,749 \\
\hline
\end{tabular}




\subsection{Hypothesis testing}

Table 4.5. Hypothesis test results

\begin{tabular}{|l|l|l|}
\hline No. & \multicolumn{1}{|c|}{ Hypothesis } & \multicolumn{1}{|c|}{ Result } \\
\hline $\mathbf{1}$ & $\begin{array}{l}\text { H1: Top management commitment and support positively impact the effectiveness of } \\
\text { TABMIS system at STs in HCMC. }\end{array}$ & $\begin{array}{l}\text { Accept } \\
\text { Sig }=0.000\end{array}$ \\
\hline $\mathbf{2}$ & $\begin{array}{l}\text { H2: Consultant support and project team competence positively impact the } \\
\text { effectiveness of TABMIS system at STs in HCMC. }\end{array}$ & $\begin{array}{l}\text { Accept } \\
\text { Sig }=0.000\end{array}$ \\
\hline $\mathbf{3}$ & $\begin{array}{l}\text { H3: User training and education positively impact the effectiveness of TABMIS system } \\
\text { at STs in HCMC. }\end{array}$ & $\begin{array}{l}\text { Accept } \\
\text { Sig }=0.000\end{array}$ \\
\hline $\mathbf{4}$ & $\begin{array}{l}\text { H4: Data accuracy, supporting tools and good infrastructure positively affects the } \\
\text { effectiveness of TABMIS system at STs in HCMC. }\end{array}$ & $\begin{array}{l}\text { Accept } \\
\text { Sig }=0.002\end{array}$ \\
\hline $\mathbf{5}$ & $\begin{array}{l}\text { H5: TABMIS software processing and quality process positively affects the } \\
\text { effectiveness of TABMIS system at STs in HCM City }\end{array}$ & $\begin{array}{l}\text { Accept } \\
\text { Sig }=0.000\end{array}$ \\
\hline $\mathbf{6}$ & $\begin{array}{l}\text { H6: System management policy TABMIS positively impacts the effectiveness of } \\
\text { TABMIS system at STs in HCMC. }\end{array}$ & $\begin{array}{l}\text { Accept } \\
\text { Sig }=0.000\end{array}$ \\
\hline $\mathbf{7}$ & $\begin{array}{l}\text { H7: Inspection and monitoring environment positively affects the effectiveness of } \\
\text { TABMIS system at STs in HCMC. }\end{array}$ & $\begin{array}{l}\text { Accept } \\
\text { Sig }=0.000\end{array}$ \\
\hline
\end{tabular}

According to Table 4.5, Beta coefficient of independent variables in the regression model, we find that independent variables have a positive relationship with the dependent variable. The results of the regression model are consistent with the studies of Hasibuan ZA \& Dantes RG (2011), Ziemba, E. and Oblak, I. (2013), Kalema BM and colleagues (2014), Omar MB et al. (2016).

Table 4.6. standardized regression coefficients

\begin{tabular}{|l|c|c|}
\hline \multicolumn{1}{|c|}{ Independent variables } & $\begin{array}{c}\text { Absolute } \\
\text { value }\end{array}$ & Ratio(\%) \\
\hline Top management commitment and support & .154 & 11.8 \\
\hline Consultant support and Project team competence & .188 & 21.4 \\
\hline User training and education & .284 & 7 \\
\hline Data accuracy, supporting tools and good infrastructure & .093 & 9.8 \\
\hline Business process reengineering & .117 & 9.2 \\
\hline TAMIS management policies & .123 & 27.7 \\
\hline Effective monitoring and control & .371 & $\mathbf{1 0 0}$ \\
\hline \multicolumn{1}{|c|}{ Total } & $\mathbf{1 . 3 3}$ & \\
\hline
\end{tabular}

\section{CONCLUSIONS}

This study examines the factors that influence the effectiveness of TABMIS through the analysis of collected data at the state treasuries in Ho Chi Minh City and identified seven factors that influence the effectiveness of the TABMIS system in order: (1) Effective monitoring and control (Beta = .371), (2) User training and education (Beta $=.284$ ), (3) Consultant support and Project team competence (Beta $=.188),(4)$ Top management commitment and support (Beta $=.154)$, (5) TAMIS management policies 
$($ Beta $=.123),(6)$ Business process reengineering $($ Beta $=.117),(7)$ Data accuracy, supporting tools and good infrastructure $($ Beta $=.093)$.

(1) Effective monitoring and control: the environment for monitoring and control in the information technology system is a very important stage, taking place throughout the whole process with the purpose of detecting errors and trying to timely overcome and support good operation. Therefore, the State Treasury needs to focus on checking and monitoring the process of using TABMIS system.

(2) User training and education: people are an important factor in the operation of an organization or system. Therefore, in order to improve the effectiveness of TABMIS system, State Treasury staffs need to improve their professional knowledge, improve computer skills and understand thoroughly the operation process of TABMIS system.

(3) Consultant support and Project team competence: the project team and implementation consultants contribute to the design, construction and support of system operation. They must constantly update changes in policies and devise strategies in accordance with the development strategy of the State Treasury as well as the public financial system in the future.

(4) Top management commitment and support: the TABMIS system needs to be oriented from top to bottom. The contradiction of the project team and the consultant needs the intervention of the board of directors. At the same time, the leaders must ensure the project's objectives are in line with the strategic objectives of the State Treasury.

(5) TAMIS management policies: a system that wants to operate effectively and achieve its objectives requires a good management policy, preventing bad situations such as hackers and viruses.

(6) Business process reengineering: the quality of the software also affects the effectiveness of the system. Therefore, the system needs to release memory to process faster, update new versions to improve system quality.

(7) Data accuracy, supporting tools and good infrastructure: modern and well-equipped infrastructure and equipment will contribute to improving the operational capacity of TABMIS system. Accurate and timely data support for reporting from the system more accurately.

\section{REFERENCES}

[1] DeLone, W.H \& McLean, E.R., 1992, Information Systems Success: The quest for the dependent variable. Information Systems Research, 3(1): 60-95.

[2] DeLone, W.H \& McLean, E.R., 2003, The DeLone and McLean Model of Information Systems Success: A Ten-Year Update. Journal of Management Information Systems, 19(4): 9-30.

[3] Hasibuan Z.A. \& Dantes R.G, 2011. Enterprise Resource Planning Implementation Framework Based on Key Success Factors (KSFs). Proceeding 2011 UK Academy for Information Systems Conference, April 2011

[4] Kamela et al., 2014. Identifying Critical Success Factors: the case of ERP systems in Higher Education. The African Journal of Information Systems, 6(3), ISSN 1936- 0282

[5] Magaireh, A. I., \& Sulaiman, H., 2019. Identifying the Most Critical Factors to Business Intelligence Implementation Success in the Public Sector Organizations. JOURNAL OF SOCIAL SCIENCE RESEARCH, 14, 2395-2414. 
152 FACTORS INFLUENCING THE EFFECTIVENESS OF TREASURY AND BUDGET MANAGEMENT INFORMATION SYSTEM (TABMIS) IN STATE TREASURIES IN HO CHI MINH CITY

[6] Ngô Hải Trường, 2012. Để TABMIS trở thành nguồn cung cấp thông tin đầu vào tài chính của Tổng Kế toán Nhà nước. Tạp chí Quản lý Ngân Quỹ Quốc Gia, số 121 tháng 7 năm 2012.

[7] Omar M.B. \& Rami M.A.W., 2016. Factors Influencing the Success of ERP Systems Implementation in the Public Sector in the Kingdom of Bahrian. International Journal of Economics and Finance. 8(12). ISSN 1916-971X

[8] Phạm Thị Thanh Hương, 2013. Kiểm soát, phòng ngừa rủi ro trên chương trình TABMIS. Tạp chí Quản lý Ngân Quỹ Quốc Gia, số 131, 2013

[9] Ziemba, E., \& Oblak, I., 2013. Critical Success Factors for ERP Systems Implementation in Public Administration. Interdisciplinary Journal of Information, Knowledge, and Management, 8, 1-19.

Received on February 1st, 2019

Accepted on March 25th, 2019 